\title{
"A Most Revolting State of Affairs": Theodore Roosevelt's Aldermanic Bill and the New York Assembly City Investigating Committee of 1884
}

\section{Edward P. Kohn}

To cite this article: Edward P. Kohn (2009) "A Most Revolting State of Affairs": Theodore Roosevelt's Aldermanic Bill and the New York Assembly City Investigating Committee of 1884, American Nineteenth Century History, 10:1, 71-92, DOI: 10.1080/14664650802299909

To link to this article: https://doi.org/10.1080/14664650802299909

曲 Published online: 19 Feb 2009.

Submit your article to this journal $\pi$

щ Article views: 49

Citing articles: 2 View citing articles ๘ 


\title{
"A Most Revolting State of Affairs": Theodore Roosevelt's Aldermanic Bill and the New York Assembly City Investigating Committee of 1884
}

\author{
Edward P. Kohn* \\ Department of American Culture and Literature, Bilkent University, Ankara, Turkey \\ In 1884 Theodore Roosevelt chaired a special committee of the New York Assembly, \\ charged with investigating corruption in New York City departments. Roosevelt \\ had also presented to the Assembly a bill to strip the city's Board of Aldermen of \\ their power to confirm mayoral appointments. The "Roosevelt bill" sought to break \\ the power of Tammany over these appointments, and reduce waste and corruption. \\ While the committee's investigation provided the press lurid examples of \\ corruption and incompetence, in the end it did little to diminish Tammany's power. \\ For Roosevelt, however, the committee hearings served as a perfect backdrop to his \\ Aldermanic bill which was eventually signed into law by Governor Grover \\ Cleveland. The parallel paths of the bill and the committee revealed Roosevelt as a \\ shrewd politico building his reputation as an urban reformer.
}

Keywords: Theodore Roosevelt; New York; reform; urban; corruption; Tammany Hall; politics; John Kelly; aldermanic bill; investigating committee

Biographers of Theodore Roosevelt have apparently come to a consensus that he was really a "Westerner," or at most, a "divided man, with one foot in the East and one in the West." Roosevelt himself may be most responsible for this image, as through his writings he carefully painted a portrait of himself as a rancher, hunter, and cowboy. Before he ever charged up the San Juan Heights in Cuba in 1898, Roosevelt had published several books reflecting his Western experience, including his four-volume history The Winning of the West. ${ }^{2}$ Roosevelt's actions in Cuba only underscored his Western image, as the Frederic Remington painting of the famous charge reflects: a lone man on horseback, wearing a broad, sombrero-like hat, and waving a six-shooter. Even after becoming president, Roosevelt published Outdoor Pastimes of an American Hunter in 1905, while his 1913 memoirs seemed to leave little doubt to future historians of the impact of his Dakota days: "It was a fine, healthy life, too; it taught a man selfreliance, hardihood, and the value of instant decision." ${ }^{3}$ Professional historians took up the theme almost immediately, with his first biographer Hermann Hagedorn publishing Roosevelt in the Bad Lands in 1921, only two years after the president's death. Since then, Roosevelt has appeared in books as a Western phenomenon. In his Pulitzer Prize-winning biography Henry Pringle barely mentioned Roosevelt's political career

*Email: kohn@bilkent.edu.tr 
before his Western sojourn, but included a chapter on "The Gentleman Cowhand."4 More recently Kathleen Dalton has asserted that Roosevelt "de-classed and re-manned himself in the West," while H.W. Brands goes so far as to say the West "helped color Roosevelt's approach to international affairs" and "influenced his approach to domestic politics." Although Roosevelt spent less than two years on his Dakota cattle ranch, it has become the subject of a disproportionate amount of attention by his biographers, as Edmund Morris's dedication of 100 pages, or about 15\% of his The Rise of Theodore Roosevelt indicates. ${ }^{6}$ Maintaining and even fostering the Western mythology surrounding Theodore Roosevelt clearly sells books and wins awards. ${ }^{7}$

Theodore Roosevelt was born in Manhattan to an old, wealthy Knickerbocker family. Initially raised in Gramercy Park, Roosevelt would later begin his political career representing his uptown brownstone city district in the New York State Assembly. From his failed bid for mayor of New York in 1886, to his serving as president of the Board of Police Commissioners from 1895 to 1897, New York City - and not the West - was the crucible for Roosevelt's political education. His earliest years as an Assemblyman in Albany reflect this. Indeed, by over-emphasizing Roosevelt's brief Dakota sojourn, coming immediately after the deaths of his mother and wife on the same day in February 1884, Roosevelt biographers have implied that his most important political experiences came after he served in the Assembly from 1882 to 1884 . John Milton Cooper even calls Roosevelt a "dilettante" during these years, as if he were no more than a wealthy playboy playing at politics. $^{8}$

Roosevelt was no rural populist from west of the Mississippi, but an urban progressive interested in clean city government and civil service reform. His earliest political experiences in Albany underscore this. Serving on the Cities Committee responsible for legislation affecting New York, Roosevelt became familiar with almost every aspect of urban life and politics, including issues dealing with labor, railway franchises, finance, and the power of the Democratic Tammany machine. His final actions in the Assembly in 1884 attest to this. In 1884 Theodore Roosevelt chaired the City Investigating Committee of the New York State Assembly, charged with looking into corruption in New York City's government, especially in the Department of Public Works. Under Roosevelt's direction, however, the committee went beyond its initial mandate to investigate corruption in other departments, including the sheriff's, as well as the unholy link between political patronage and graft. The hearings provided a number of dramatic episodes for the New York press. At one point during the proceedings the committee called before it Mayor Franklin Edson and the Tammany boss "Honest" John Kelly, and even held hearings in the Ludlow Street Prison to take testimony from prisoners. The committee's final report recommended a series of bills to reform New York's municipal government, legislation that simply added to Roosevelt's previous efforts to reform city government through state legislation, including the Aldermanic bill to strip the Board of Aldermen of its power and invest it in the mayor instead.

In his autobiography, Roosevelt called his chairing of the investigating committee "the most important part I played" in the New York legislature. 9 Significantly, Roosevelt, writing 30 years after the event, stated that the most significant result of the committee was his Aldermanic bill, which was signed into law in March 1884, only days after the committee issued its final report. The bill sought to remove from the 
appointed Board of Aldermen the power of confirming mayoral appointments and enhance the executive power of the mayor, thus, it was hoped, diluting the power of Tammany Hall over appointments to city departments and reducing corruption and waste. However, either Roosevelt forgot that this bill had been introduced before the committee began its hearings, or perhaps the bill and the committee had become inseparable in his memory. Certainly this small slip by Roosevelt underscored the relationship he viewed between the Roosevelt bill which sought to strip the alderman of the confirming power, and the Roosevelt committee which sought to strip Tammany and its minions of their financing.

Roosevelt's committee sat for several months and provided the public a window into the scandalous state of city government. Yet even though Roosevelt historian William Henry Harbaugh believes that the committee "conducted one of the most sensational investigations of municipal government to that time," the results of the committee hearings paled in comparison to the exposure of the Tweed Ring in 1871, which led to the downfall of longtime Tammany boss William Tweed, and the Tilden Commission which followed. ${ }^{10}$ The later 1886 revelations concerning the bribing of aldermen to secure the franchise for building a surface railway down Broadway also created much more of a spectacle, and led to the arrest or flight of most of the Board. Finally, the reform bills suggested by Roosevelt and his committee, while an impressive body of legislation, in the end appeared unable to break the power of the machine in New York. Perhaps because of this, historians of municipal reform, New York City, and Tammany Hall fail even to mention this committee.

Even among Roosevelt biographers the committee has received little attention. The emphasis on Roosevelt's Western identity explains part of this. It may also result from the fact that in looking at Roosevelt's life, the committee hearings are overshadowed by the deaths of Roosevelt's wife and mother on the same day, interrupting both the hearings and Roosevelt's political career. A number of writers see the hearings mainly as, in the words of H.W. Brands, "therapy for a grieving man."11 The lack of interest in the committee may also result from the simple fact that the topic of municipal reform is not a very exciting one, especially when the research requires poring over thousands of pages of testimony before the committee. Finally, research into this topic has been made difficult by the fact that after his wife's death Roosevelt destroyed any letters, photographs, or diary entries related to her, thus excising from the written record much of the material from these very months.

Whatever the reason, the oversight of this chapter in Roosevelt's early political career is a critical one. Chairing the committee was an important step in Roosevelt's career, both in New York state and New York City. Championing the Aldermanic bill and chairing the committee marked Roosevelt as an urban reformer, thus representing an increasingly important wing of the Republican party. The committee also represented an important part of Roosevelt's political education. Despite the view that Roosevelt was only a wealthy 'dilettante' playing at politics, the committee hearings, the use of a sympathetic press, and the simultaneous championing of the Aldermanic bill clearly illustrate that Roosevelt was in fact quite a serious and experienced player of the urban political game, as he sought to use his seat in the state legislature to bring about municipal reform in New York City. 
In particular, the committee hearings provided Roosevelt the perfect, sensationalist backdrop to garner support for his Aldermanic bill. As chairman of the committee, Roosevelt steered the hearings into areas not really authorized by the Assembly. Although Honest John Kelly emerged virtually unscathed from the hearings, Roosevelt may have achieved his purpose simply by highlighting the way the Tammany machine controlled city government, fostered corruption, and undermined the independence of the mayor. ${ }^{12}$ All of this served Roosevelt's purposes quite well, even though the hearings offered little new to the close observer of New York government, and only resulted in the arrest of a single, low-level city employee. The committee hearings paralleled exactly the Aldermanic bill's journey through the New York Assembly, and its eventual signing into law by Governor Grover Cleveland. Finally, although throughout his entire political career Roosevelt asserted his independence from faction and party control, the young Assemblyman did the Republican party a great service in embarrassing Tammany and seeking to undermine its power.

Roosevelt entered the Assembly in 1882. He was re-elected twice more to singleyear terms, and in his three years in the Assembly Roosevelt acquired a reputation as an independent Republican and something of a reformer. Right from the beginning Roosevelt sat on the Assembly's City Committee, the most important vehicle for shaping the laws of New York City, which was under the authority of Albany. Any laws concerning the city's finances, street paving, water supply, wages for police and firemen, all were written in Albany, and not in the city.

The year 1884, and Roosevelt's third term in Albany, promised to be a great one for the 25-year-old. Republicans had regained a majority in the Assembly, and Roosevelt was actually up for the position of Speaker after making something of a name for himself as leader of the Republican minority the previous year. Roosevelt, however, lost the race for Speaker when the Republican machine engineered his defeat by bringing great pressure on Roosevelt's fellow Assemblymen. On the eve of the 1884 presidential election, there was no way the Republican bosses could have allowed the independent Roosevelt into such a prominent position. Instead, Roosevelt had to be content with the chairmanship of his City Committee, and the chair of a special committee to investigate corruption in the city, namely in the Department of Public Works. ${ }^{13}$

Roosevelt's investigating committee, though, was hardly a turning point in the efforts toward municipal reform, as Roosevelt was coming into the game fairly late. The New York Times had exposed the infamous Tweed Ring in 1871, with disclosures of malfeasance such as the fact that the building of the new city courthouse would cost twice as much as the United States purchase of Alaska from Russia. ${ }^{14}$ Boss Tweed's eventual prosecutor was Samuel Tilden, the man American history best remembers as the loser of the 1876 presidential race against Rutherford Hayes. But Tilden was also at the forefront of municipal reform. He was elected governor of New York in 1874, and established a commission to investigate the city the following year. In 1877 the commission published its report, saying, "We place at the head of the list of evils under which our municipal administration labors, the fact that so large a number of important offices have come to be filled by men possessing little, if any, fitness for the important duties they are called upon to discharge."15 
The Tilden Commission helped spark a new interest in municipal reform, especially the spoils system that established a close relationship between the party in power and the men who controlled the purse strings of the city. In 1880 the New York Civil Service Reform Association was established, with members including E.L. Godkin, Theodore Roosevelt, and other businessmen and professionals, with the idea that reform should be based on careful investigation of municipal administration. The following year this association, along with reform associations in other cities, formed the National Civil Service Reform League. Their agitation helped pass the Pendleton Civil Service Act in 1883, which created an oversight committee for the United States civil service that Roosevelt would eventually serve on for six years in the late 1880s and early 1890 s. ${ }^{16}$ All of this is simply to say that Roosevelt was not so much breaking new ground in municipal reform as indicating a further step along a nation-wide process that had begun a decade earlier.

And what a task faced these reformers. Writing in 1893 the British historian James Bryce in The American Commonwealth stated: "There is no denying that the government of cities is the one conspicuous failure of the United States. The deficiencies of the National government tell but little for evil on the welfare of the people. The faults of the State governments are insignificant compared with the extravagance, corruption, and mismanagement which mark the administrations of most of the great cities." ${ }^{\prime 17}$ Bryce and others pointed to some of the sources of the problem: the rapid growth of American cities and the resulting massive public works projects; the fact that most city residents did not pay taxes, so were apathetic to city politics; the diffusion of power among a faceless Board of Alderman rather than a single, strong executive; the ignorant and malleable population of immigrants; and the interference of the states in city affairs. As historian Clifford Patton writes, "What greater advantages could the scheming politicians have asked than a broad program of civic improvements, an apathetic public, a weak charter that failed to fix responsibility, and a conniving legislature? The scene was perfectly set. Machine politics, graft, and party prejudice stepped in to profit by the confusion." 18

In New York the nemesis of the reformers was "Honest" John Kelly, who ruled Tammany from 1874 to 1886 . He was dubbed "honest" apparently because he was quite open about the close relationship between party loyalty, nominations to lucrative offices, and the resulting money that would then flow back to Tammany. Kelly controlled two New York newspapers, the Star and the Evening Express, and told the Board of Excise Commissioners not to grant a license to any saloon unless it paid for two subscriptions to the Star. ${ }^{19}$ At one point in its hearings Roosevelt's committee would call Kelly before it and question him and the mayor about a secret meeting that occurred prior to the previous election, where they discussed post-election appointments to city offices.

At the opening of the new Assembly in January 1884, Roosevelt introduced three bills that indicated how reform of New York's municipal administration might be achieved. The first bill would give the mayor complete power, without reference to the aldermen, to appoint department heads. Roosevelt and other reformers' model for reform was Brooklyn, where a similar law had invested Mayor Seth Low with sole appointing power. The result seemed to be better department heads, and more public 
interest in municipal politics with a visible and more powerful mayor. Indeed, in Brooklyn more people voted for mayor than voted for governor. Roosevelt's second bill called for limiting municipal indebtedness. In New York the city's debt had increased more than tenfold over the previous quarter century, fueled by massive public works projects that also made many politicians rich. Finally, Roosevelt's third bill sought to break the Tammany Hall-saloon axis by establishing a high license fee to sell liquor in the city. The first two bills would eventually be passed, with the bill concerning the mayor's power of appointment labeled by the press the "Roosevelt Bill." The license bill, however, failed, but presaged the time when Roosevelt, as President of New York's Police Commissioners, would again go after the unholy alliance between politicians and saloon owners.

Roosevelt achieved more immediate success when the Assembly voted to establish a special Assembly committee to investigate New York City government, with Roosevelt as chairman. Roosevelt's associates on the committee were two Republicans, including his good friend William O'Neil, and two Democrats who were largely sympathetic to Roosevelt. The resolution specifically targeted the Department of Public Works under Commissioner Hubert O. Thompson, under whose management its annual expenditure had risen $65 \%$, or almost $\$ 5$ million, from only the year before, while taxes in the city between 1883 and 1884 had risen by over $\$ 3$ million. The resolution also noted that the Union League Club and the city press had charged Thompson with fraud, and that in general "Public sentiment demands a thorough investigation of local government" in New York City. ${ }^{20}$

The committee met for the first time in the Metropolitan Hotel in New York City on 19 January only four days after the Assembly passed the resolution. Roosevelt and his fellow committee members would gather in the city three days a week, on Fridays, Saturdays and Mondays, allowing them to return to Albany for the rest of the week. This was a very busy time for Roosevelt. He was still chairing his Cities Committee in Albany, writing and championing bills in the Assembly; and he was commuting to Manhattan for his committee hearings as well as attending to his very pregnant wife who was staying at Roosevelt's mother's home just west of Fifth Avenue on $57^{\text {th }}$ Street. The hearings themselves displayed Roosevelt's growing political acumen at only age 25 . As chairman Roosevelt had to deal with hostile witnesses and their counsel, obdurate members of his own party, the mayor of New York, and even the Tammany boss John Kelly. All the while Roosevelt ensured a constant stream of sensationalist testimony to the press and public.

While Roosevelt had been successful in calling for an independent Assembly investigating committee, the New York Senate had convened its own investigating committee which was holding hearings simultaneously in the mayor's private office in City Hall. The Senate, too, was very interested in hearing from Commissioner Thompson and had left a subpoena for him in his office at the Public Works Department. Perhaps foreseeing a conflict with the Senate, Roosevelt had personally gone to see Thompson and secured a promise from him to appear before the Assembly committee. Thompson fulfilled his promise to Roosevelt, ignoring the Senate subpoena. "The Senators were mortified," the Times reported, and held Thompson in contempt. They were left "smoking cigars and discussing the situation," as they dispatched the Sergeant-at-Arms to hunt down Thompson. ${ }^{21}$ Back at the Assembly hearings, the questioning of Thompson had barely 
begun when a messenger interrupted the proceedings and handed Thompson a telegram from his counsel demanding his appearance before the Senate committee. Laughing, Thompson read the telegram to Roosevelt and his colleagues, and then loudly told the messenger, seemingly for the benefit of his audience, "Tell them I will leave here in five minutes," a dismissive comment that drew laughter from those assembled. Roosevelt must have been displeased to be outmaneuvered by both the chief target of his committee investigation, as well as by the Senate.

The committee was forced to adjourn until Monday, at which time Thompson failed to appear. This further embarrassment, and apparent overshadowing by the Senate committee, forced Roosevelt to assert the very relevance and independence of his committee. "The House strongly and plainly showed that it did not wish the committee to join with the committee of the Senate in making this investigation," Roosevelt noted. "More than that, owing to the far broader scope of our inquiry, it was evident that we would not go into matters in the same way in which the Senate committee probably would... We do not for a moment admit that we have not the right to the witness, but we also do not propose to allow ourselves to be drawn into a controversy with the committee of the Senate." 22 Indeed the New York Herald reported that the Republican Speaker of the Assembly had traveled from Albany to New York to pressure Roosevelt's committee to simply join forces with the Senate's own investigation, but Roosevelt had refused even to listen. ${ }^{23}$ Instead, the committee was forced to temporarily abandon its investigation into Commissioner Thompson and the Department of Public Works, the supposed focus of the committee in the first place, and instead turn to other municipal departments.

The comedy of errors and evasions continued. The Register, John O'Reilly, had only been in office three weeks, and could offer little information, while his predecessor had gone to Cuba, "on the advice of his physician." ${ }^{24}$ Next, the committee called the County Clerk Patrick Keenan. Keenan was the exact sort of politician Roosevelt and other reformers wanted to target: Keenan was a former alderman, a former liquor dealer, and of course a Tammany man. Keenan readily admitted to the committee that he had paid $\$ 7500$ to Tammany Hall for his nomination, and had kept about $\$ 14,000$ in fees paid to his office. Yet apparently Keenan knew very little about what his office actually did, and spent little time there, leaving the office in the care of his deputy. As he explained to the committee, "A man in the city of New York who is considered a local politician - they have a great many things to attend to sometimes and they can't attend to the business at all times." This led Roosevelt to ask, "Do I understand you to mean that your duties as a local politician occasionally override your duties as clerk?"25 Two years later, writing an article for The Century entitled "Machine Politics in New York City," Roosevelt recalled that Keenan openly admitted to attending his political duties over his official department responsibilities, duties that included "seeing politicians, fixing primaries, bailing out those of his friends (apparently by no means few in number) who got hauled up before a justice of the peace, etc., etc." "This man's statements," Roosevelt concluded,

were valuable because being a truthful person of such dense ignorance that he was at first wholly unaware his testimony was in any way remarkable, he really tried to tell things as 
they were; and it had evidently never occurred to him that he was not expected by everyone to do just as he had been doing - that is, to draw a large salary for himself, to turn over a still larger fund to his party allies, and conscientiously to endeavor, as far as he could, by the free use of his time and influence, to satisfy the innumerable demands made upon him by the various small-fry politicians. ${ }^{26}$

The New York Herald noted that the clerk had spoken of his ignorance of his duties "with childlike simplicity," while asserting in an editorial, "There is a well founded, popular conviction that each of these important offices is controlled by machine politicians and run for political purposes. The flagrant abuse of the fee system, which flourishes in them, is notorious." ${ }^{27}$ In fact they were so notorious and well-known that the paper questioned the very purpose of the investigation, believing the stories of abuse in the clerk and registrar's offices to be "so familiar to the public that it needed no investigation to discover it." Such investigations were merely political, the Herald concluded, and would not result in any legislation.

Arguably the Herald was correct. For those familiar with the workings of city government, the revelations by the clerk were hardly new information. It was widely known that officials paid for their offices with the understanding that they would reap profits in the form of fees or false expenses charged to the city. Moreover, the paper could not be blamed for doubting whether the investigations would produce any meaningful legislation. Certainly the hearings were political in that they were conducted by an assembly committee with a Republican majority targeting a Democratic city government with strong ties to Tammany Hall. John Kelly had helped elect Franklin Edson in 1882 and "received a vast amount of patronage in return." 28 Simply embarrassing New York Democrats would have been sufficient. Yet what the Herald ignored, although Roosevelt himself surely did not, was the fact that only a few days later his Aldermanic bill was due for a second reading in Albany. Exposing the deficiencies of a system that allowed aldermen rather than the mayor to appoint officials as political favors served as a perfect backdrop to Roosevelt's campaign to pass the "Roosevelt Bill."

Although the Public Works Department was the original focus of the committee's investigation, the Sheriff's Department became a prime target for its examination. Sheriff Alexander Davidson testified accompanied by his counsel, future Democratic Congressman from New York, William Bourke Cockran. Almost every aspect of the sheriff and the city jail, the Ludlow Street Prison, was investigated, including transportation of prisoners, food, execution of prisoners, and the conditions inside the prison itself. Indeed, in one of the most spectacular episodes of the committee hearings, Roosevelt and his fellow members actually held hearings in the Ludlow Street Prison and took testimony directly from prisoners. Once again Roosevelt displayed his talent for the sensational and dramatic, and his understanding of the power of publicity.

One of the first things that Sheriff Davidson disclosed about the running of the jail was that he personally owned the van and team of horses used to transport prisoners. The fact that he had bought the team from his predecessor indicated pretty strongly that this was a money-making scheme handed from one sheriff to the next. When asked about the cost of the van and horses, Davidson replied, "Is that not a matter of private affair?" Roosevelt replied, "It is not a matter of private affair; we want to find out if the fees of this office are or are not excessive; therefore, we want to find out what 
the cost of your plant is." When the sheriff continued to claim it was a private affair, Roosevelt said:

You say you consider that a private question; the committee radically disagrees with you; you are a public servant, you are not a private individual; we have a right to know what the expense of your plant is; we don't ask for the expense of your private carriage that you use for your own conveyance; we ask you what you, a public servant, pay for a van employed in the service of the public; we have a right to know; it is a perfectly proper question. $^{29}$

Davidson also noted that his office hired private carriages, or "hacks," to convey prisoners, including convicted murderers. When asked about the cost of hiring a carriage, the sheriff replied, "It depends entirely upon the generosity of the person who owns the hack ... When a deputy sheriff is handcuffed to a criminal, he is not apt to stand long for a dollar or two dollars." In other words, deputy sheriffs stood on the street manacled to their prisoner, and hailed carriages in the same way we would hail a taxi!

Even the execution of prisoners seemed to be a money-maker for the sheriff and his deputies, 20 of whom were paid to be in attendance. When asked about the necessity of having 20 deputies in attendance, the sheriff replied he was authorized to keep the peace. But, it was pointed out, the executions took place inside the prison: "Why is it necessary to have twenty persons inside of the prison, twenty deputies to attend an execution?" The records also indicated a large fee paid to Michael McGloin and Pascal Majone of over \$390. Asked about these expenses Sheriff Davidson replied, "It is a contract that I make between the party that cuts the rope and myself." The counsel for the committee, Charles Miller, began to ask the name of the person who cut the rope, but Roosevelt, seeing the real point of attack, cut him off. "You need not ask that," he said, then turning back to Davidson: "You pay $\$ 396$ to the party that cuts the rope?" When both the sheriff and his counsel defended the expense, Roosevelt lectured them: "Mr. Sheriff, it is perfectly true that there is no occasion for squeamishness in answering a question like this; the occasion for squeamishness would be in taking advantage of your position for charging too much for things like this about which you think no inquiry would be made." 30

The sheriff s clerk Jacob Wertheimer, and the under sheriff, Joel Stevens, were also called to testify, about topics including the practice of over-charging the city for a prisoner's stay in the jail and the cost of transporting prisoners. At the end of testimony on 1 February Wertheimer was arrested on the charge of collecting in the name of the sheriff in 1883 at least $\$ 5000$ to which the sheriff was not entitled. The New York Times, which reported the committee hearings with great interest and sympathy for Roosevelt, noted almost in passing how Tammany came to the rescue of one of its own. When Wertheimer appeared in Police Court he was represented by a state senator; his $\$ 10,000$ bail was posted by one Peter McGinnis, an East Side liquor-dealer; and later that night a group of Tammany men went to the judge's home to secure Wertheimer's release. ${ }^{31}$

The blatant example of corruption offered by the committee's probe into the Sheriff's Department, and the subsequent arrest of the under sheriff on 1 February provided an ideal backdrop for Roosevelt's championing of his Aldermanic bill. The Roosevelt bill 
came up for a second reading in the Assembly on 5 February. In what the Times referred to as an "excellent speech," Roosevelt defended the bill by citing the low character of the aldermen, and accusing them of being merely tools of the political machine. Moreover, aldermen were largely unknown, while any mayor, though perhaps equally as dishonest or corrupt, was at least a highly public figure and subject to being kicked out of office at the next election:

We have in New York this curious condition of affairs: The Mayor has the nominal power in the making of appointments: two or three outsiders, through their tools in the Board of Aldermen, have the real power. It would be bad enough if we really were under the control of that contemptible oligarchy, the Board of Aldermen. But we are, in fact, under the men who are behind the Aldermen... The Aldermen represent the lowest stratum of New York life. It is possible he may suffer at the hands of a Mayor under such a law as this. We can at least hold him responsible and at the end of his term remove him. Now we are helpless... I would prefer a responsible autocrat than an irresponsible oligarchy which is composed of the worst, instead of the best, elements of our people. ${ }^{32}$

Despite opposition from Democrats, including one Tammany man who cited Jefferson's opposition to centralizing power, and proclaimed "Let us bear the evils we have rather than fly to those we know not of," the Roosevelt bill was ordered to a third reading and thus probable passage by the lower house. With a sense of triumph Roosevelt wrote to his wife of his "victory" in the Assembly, having "made a nice strike in my speech on the aldermanic bill." 33

Upon returning to New York City, Roosevelt's committee was faced almost immediately with the matter of mayoral appointments and the power of the Tammany machine. John B. Haskin, a former judge, city attorney, president of the board of education, and former Congressman, wrote a letter to the New York Sun charging the current mayor of New York, Franklin Edson, with nepotism, by securing posts for Edson's son and also his nephew. While Haskin's letter to the editor was chiefly trying to embarrass Edson, Roosevelt and his committee seized upon the fact that, according to Haskin, Edson had met with a number of men before his election to discuss subsequent nominations, both to the Board of Aldermen and to city departments, and this meeting had taken place in the home of none other than John Kelly, the Tammany boss. Only days after his speech in support of the Aldermanic Bill in Albany, here was a chance for Roosevelt to illustrate perfectly the way nominations to city government were compromised by aldermen having the power to block the mayor's appointments. Edson was an anti-Tammany county Democrat, and the meeting with Kelly was purportedly for the purpose of dividing nominations between the county and city democrats - illustrating perfectly the influence of Kelly over the aldermen, and the aldermen's power over the mayor's nominations.

The city now enjoyed the spectacle of seeing both the mayor and the Tammany boss called before the Roosevelt committee on 9 February. In front of a packed parlor of the Metropolitan Hotel, Mayor Edson denied that any deals had been made - "No pledge or promise was made or suggested in regard to my appointments" - yet admitted to meeting at Kelly's house with the men who would later receive appointments as fire commissioner and police commissioner. The committee then called John Kelly, who did a fair job of not answering the questions put to him. When asked if he had 
any objection telling the committee about the meeting at his house, he replied, "I have an objection, and I don't propose to tell it. The meeting was a private one, and this committee has no right to ask about it." Yet he freely admitted meeting with the mayor and future department heads, as well as with aldermen to discuss the mayor's appointments. With no proof of any deals made other than the testimony of a disgruntled foe of the mayor, little came of Edson and Kelly's testimony. Indeed, the committee seemed to have overreached its mandate concerning municipal government per se, and the calling of the mayor and a Tammany boss may have seemed like a bit of hubris on the part of Roosevelt and his committee, or that they had simply been manipulated by someone with a political axe to grind. Both Edson and Kelly stated firmly that the committee had no business investigating a private meeting that occurred before Edson even took office. Adjourning until the following Saturday, Roosevelt read a statement from the committee defending its actions: "The charges were of such a grave nature as under the charter I believe it is a felony for the mayor or any officer to make such a bargain as he was there stated to have made. The committee did not feel they could possibly omit trying to get at the truth of the matter and they therefore subpoenaed those gentlemen from whom they thought they would be most likely to find out what took place at that meeting." ${ }^{34}$ While the committee briefly pursued the matter further, it generally turned back to its investigation of the city departments.

The New York Sun echoed Edson and Kelly's objection that the committee had overstepped its mandate. In an editorial entitled "The Power of Legislative Committees," the paper called on the Assembly to limit their power. "The investigating committees of the present Legislature have roamed far a-field, and furnished much interesting reading matter for the newspapers," the editors noted, "but we think they have set a most pernicious example in magnifying their own powers to such an extraordinary extent as has lately been witnesses in this city." 35 Such public criticism may also have contributed to Roosevelt's decision not to pursue further the matter of the mayor's promises to Honest John.

For Roosevelt, though, the calling of Edson and Kelly may have served its purpose: not to make their dealings the focus of his committee, but to expose them to the public as a way to garner support for his Aldermanic bill. The press obliged, with headlines such as "Shameful Revelations" and "Facts to Astonish Decent Citizens." ${ }^{36}$ Harper's Weekly, edited by fellow reformer George William Curtis, depicted "The Three Bosses of Gotham" at sea in a bowl labeled "New York City Democracy," with John Kelly, the "City Charter" tucked under his arm, at the helm trying to steer between "Tweed Rock" and "Albany Reef." The cartoon showed the bosses about to founder on a branch labeled "Grand Jury, Public Opinion, Investigating Committee," and asked the question of the reader, "What are you going to do about it?"37 All this could only provide positive publicity for the Aldermanic bill, due for its final reading and expected passage in the Assembly on Wednesday, 13 February. Moreover, the following day a large rally was scheduled to take place at Cooper Union to help its passing the state Senate. General Ulysses S. Grant himself was scheduled to be vice-president of the meeting. ${ }^{38}$ In announcing the Cooper Union rally the Times referred to the Kelly-Edson meeting as proof of the need for reform. ${ }^{39}$ The concurrence of Roosevelt's advocacy of his Aldermanic bill, a product of his Cities Committee, and his chairing 
of the investigating committee, represented a high watermark in Roosevelt's development as a professional, Republican politician, as well as a key step in the development of his reputation as an urban reformer.

Despite his wife Alice's advanced pregnancy, Roosevelt returned to Albany Tuesday, 12 February, prepared to speak on behalf of his Aldermanic bill the following day. On Wednesday he recorded out of the Cities Committee 14 bills, and received a telegram reporting the birth of a baby girl. With the third reading of his bill imminent, Roosevelt requested a leave of absence from the Assembly as he received the congratulations of his fellow members. Before any debate on the bill could begin, Roosevelt received a second telegram from New York City. Both his wife and mother lay dying. The Aldermanic bill was laid aside and Roosevelt caught the next train for the city. The next day Roosevelt's mother Mittie Bulloch died of typhoid fever and his wife Alice died of Bright's disease. Their double funeral was held at the Fifth Avenue Presbyterian Church two days later.

In the meantime, the rally in support of the Roosevelt bill went forward at the Cooper Union, with the majority of participants unaware of the tragedy. The meeting illustrated how the Aldermanic bill and the committee hearings had combined in the public mind. Discussing the meeting in an editorial the New York Times noted that the Board of Aldermen's action on the Mayor's nominations to city departments "is always determined by political deals and corrupt bargains," while passage of the Roosevelt bill "would remove the source of demoralization in general politics which comes from the bargaining over the spoils of the city." 40 At the meeting that night Douglass Campbell made several references to the committee hearings in his keynote address. "We know full well," he said, "that this is one of the worst governed cities in the world. We need no investigation by the Assembly to tell us of the petty swindles, the embezzlements, and extortions daily practiced in the offices of the County Clerk and Sheriff ... We did not need a revelation from the Hon. John B. Haskin to inform us that our present Mayor had by a degrading bargain with John Kelly secured his nomination to that high office." The aldermen, Campbell said, "levying contributions on every class in the community ... are our virtual rulers. They appoint all our high municipal officers, for with them the right of confirmation is substantially the power of appointment." Instead, municipal government must cut out the aldermen and party managers by drawing a straight line between the people and the mayor. To effect this, one legislator in Albany had introduced this bill. "He is in earnest," Campbell declared, "for whatever Theodore Roosevelt undertakes he does earnestly, honestly, and fearlessly." It only remained for the people to let the legislature know that the people stood behind Roosevelt and his bill. ${ }^{41}$ In response to the vote on a resolution showing support for the bill, the crowd at the Cooper Union answered with a resounding "Aye!" 42

Less than a week after the rally, and only four days after the double funeral for Alice and Mittie Roosevelt, Roosevelt was back in his seat in the Assembly, speaking on behalf of the Aldermanic Bill. Roosevelt condemned

... the aristocracy of the bad. This is the class of office-holders; it is composed of men who fatten in the public offices upon the plunder wrung from the working man and from the 
taxpayer alike; who hold their grip upon us by means of the patronage that we, like the fools we are, leave in their hands; who unite themselves with every bad element in the community; who unite with those who live by trading on the vices of the community; who can count with absolute certainty upon the support of the lowest liquor-sellers; who can count upon the support of all that is vile and bad throughout the great cities - for men such as these are the professional politicians of the lowest type. ${ }^{43}$

Despite vigorous politicking by Tammany representatives on the floor of the Assembly, the bill passed by a vote of 70 to 51 , with 12 Democrats supporting the measure and eight Republicans voting against it. Seven Assemblymen were absent that day, reported the Times, "afraid to vote against the bill because of the political pressure put upon them," but also "afraid to take the opposite course because of the criticism which would follow them." 44 The bill now went to the Senate's own Cities Committee.

The investigating committee would reconvene only on 23 February. The record of the Hearings indicates nothing about Roosevelt's tragedy. There was no call for a moment of silence or testimonials offered, as occurred in the Assembly in Albany. And while of course ink on a page does not easily reflect emotion, still, there appeared to be no change in Roosevelt's tone or in the proceedings in general. It has been noted that one of Roosevelt's favorite sayings was: "Black care rarely sits behind a rider whose pace is fast enough.” Previous Roosevelt biographers are probably right: Roosevelt tried to turn his back on his grief, and threw himself into his work.

While the Department of Public Works and its commissioner Hubert Thompson had been the initial focus of the committee, the richest lode that the committee mined turned out to be the Office of the Sheriff and his personal fiefdom, the Ludlow Street Prison. First the warden of the jail was called, one James Bowe, brother of the previous sheriff. The committee noted that the warden charged the city 75 cents a day for each prisoner's food, even though a large number of prisoners fed themselves. The warden was also asked about a bill that the city paid for over $\$ 600$, apparently to a furniture dealer for Brussels carpets $(\$ 175)$, a parlor suite $(\$ 150)$, a walnut table, and other items. The committee counsel asked, "Where did that furniture and bedding go?" "That is in my rooms," the warden replied. ${ }^{45}$

The testimony of a former deputy warden at the jail, Philip Kiernan, former keepers, and former prisoners at the jail attracted the attention of the committee and the press. Kiernan and others testified that a kind of bar was operated in the jail out of one of the cells, selling beer and tobacco, and that the proceeds went to the sheriff. In fact, it was a common sight to see jail keepers drunk, and once on a Sunday the chaplain was forced to complain about the noise and profanity coming from the bar. The committee also heard testimony that rooms were rented to prisoners for the purpose of entertaining women. The sheriff, warden, and keepers would confiscate property and not return it. The prison was overcrowded, with three or even four prisoners in some cells, and the prisoners were covered with lice. There also seemed to be a custom of asking prisoners for a sort of exit tax of $\$ 1.50$ when they were discharged. Kiernan testified about the bad food and putrid meat served to prisoners, and the bad language and violence directed at prisoners. Female visitors, it was noted, were not searched when they came into the jail, thus perhaps carrying contraband, and the tin buckets used to transport food to the prisoners were also used for cleaning the floors. ${ }^{46}$ 
It was perhaps this testimony, and the attention it received in the press, that led to the committee taking the dramatic step to hold further hearings inside the jail itself. Legally this was required, as the committee had no authority to call prisoners before it to testify. The committee first heard from Augustine Ralph McDonald, the jail librarian, who had been a prisoner for five years. McDonald testified that there was a systematic effort to extort money from prisoners for better conditions. When McDonald was unable to pay this money, he had been sent to a cell with no warm water, and next to a toilet so that foul air would come through a hole in the wall. He had been told it was "all a question of money" whether he could get out of that cell, and the deputy warden had asked him for \$250. McDonald explained the system of extortion and described the near-constant drunkenness of the keepers. He also testified about the bad food, with the leftover meat trimmings bought from butchers to make soup. And he said that the warden had offered to carpet his cell if he did not testify.

The prisoner's litany of abuses continued. Some keepers continued to draw pay from the jail even after they had been discharged. The keepers supplied whiskey to and borrowed money from prisoners. Prisoners were allowed out of their cells as long as they had money to spend at the bar, and the revelry would continue late into the night, keeping McDonald awake. Keepers took personal items from the prisoners and did not return them. McDonald testified that when three keepers had been discharged the previous May they had three closets filled with furniture and other items taken from the prisoners' cells. Prisoners were not given changes of clothing for months, and those responsible for serving food would be so filthy that the vermin on them would drop onto the food. When asked if he knew anything about women being brought in for the prisoners McDonald replied, "Well, the place goes by the name of the sheriff's whore-house." Once when he heard there were "strumpets" in the cells alongside his, McDonald got very indignant and complained: "I was willing to be imprisoned anywhere, but not in a house of ill-fame, and that the State of New York had no authority to do that." ${ }^{\prime 7}$

Further testimony by other prisoners simply confirmed the stories the committee had already heard about drunkenness, extortion, theft, prostitution, bad language, filthy cells, and putrid food. Once again a city department had become the personal estate of a corrupt official, a situation allowed by Tammany's control over the aldermen, and the aldermen's power of confirmation of mayoral appointments. Once again the press covered the lurid tales of waste and corruption ("Abuses in Ludlow Street Jail Brought to Light," one headline proclaimed). ${ }^{48}$ And once again the Roosevelt committee hearings paralleled the progress of the Roosevelt bill through the state legislature. While the committee heard testimony on 1 March regarding extortion of the prisoners by drunken keepers at the jail, the Senate passed the Aldermanic bill on $5 \mathrm{March}$, "an important triumph for the cause of municipal reform in this city," a Times editorial declared. ${ }^{49}$ All that was left now was for New York governor Grover Cleveland to sign the bill into law. Even here, the conclusion of the investigating committee and its final report provided a perfect backdrop for the Roosevelt bill becoming law.

The committee adjourned only days before its final report was due on 14 March. Roosevelt set himself to the task of writing the remedial bills that would accompany 
the report to the Assembly, while the counsel for the committee began drafting the report itself. With the deadline looming, counsel for the committee submitted a draft of the report that Roosevelt and the other committee members found completely inadequate as it glossed over the most damaging testimony. The committee chose Roosevelt to write a new report. He stayed up all night, wrote through breakfast, wrote on the floor of the Assembly as other bills came up for discussion, and sent the report to the printers, which delivered the final report in time for the committee to read and sign it before Roosevelt stood to introduce it to the Assembly. ${ }^{50}$

The report began with a sweeping statement about city governance:

In hardly one office or department, irrespective of the political affiliations of the incumbents, did we find both honesty and efficiency; indeed, the whole government of the city and county of New York, so far as we examined it, seemed to be in a condition that was absolutely appalling; a condition that would not be possible for a moment if the majority of the voters were alive to the danger of their position, and were actuated by a proper public spirit; and in this connection we would like to say that the manner in which the best citizens of both political parties in the city of New York seem to hold themselves aloof from politics is deserving of the most unqualified censure. ${ }^{51}$

In the report Roosevelt again took aim at the board of aldermen and the nefarious powers behind them: "Under the present system the men who nominally hold the offices are not the ones who really exercise the power, but that the latter, on the contrary, are generally outside the political parties, who cannot be held responsible to the people for their deeds and misdeeds." The report then went through each department investigated and noted its findings. In the County Clerk's Office the clerk of the city of New York drew a salary of $\$ 3000$, but the current clerk had kept $\$ 13,700$ in fees, while his predecessor had kept $\$ 36,000$. The Register did not draw a salary, and had only held his office since 1 January. "But," the report claimed, "it appears clearly from the evidence that if subsequent months pay him as well as the month of January did his net income for the year will amount to between $\$ 30,000$ and $\$ 40,000$.” The sheriff was getting paid massive compensation for services that cost him very little, such as for transportation, food, and even hangings. But it was the committee's investigation of the Ludlow Street Jail that uncovered, in the report's words, "a most revolting and almost incredible state of affairs" where "drunken and brutal keepers" operated a "thorough system of extortion and blackmail." The sheriff, one of the city's top law enforcement officials, was in reality basically the ringleader of a massive scam involving the deputies and keepers at the jail. ${ }^{52}$

Roosevelt followed his submitting of the report with the introduction of nine bills, mainly having to do with reforming the system of fee collection in the various offices, which Roosevelt claimed could save the city $\$ 200,000$ a year. But the bills also included one to change the office of Controller from an appointed to an elective office, and a bill to elect a president of the Board of Aldermen to preside over all committee meetings. Most of these bills were eventually made into law, but really, none of them were as important as Roosevelt's Aldermanic bill which Governor Grover Cleveland signed into law on 17 March, only a few days after the investigating committee submitted its report. Indeed, it can be argued that this was the most important feature of the committee hearings: they provided the perfect sensational backdrop for Roosevelt to 
press for the aldermen of New York to be stripped of their confirming power, thus diluting the power of Tammany Hall and the likes of Honest John Kelly. The remedial bills that accompanied the committee's report sought to dilute this power further, as well as deprive Tammany of tens of thousands of dollars through reform of fee collection in city departments.

Roosevelt's efforts did not come close to ending the power of John Kelly. However, the Aldermanic bill may have hastened Kelly's departure as Tammany boss later that year. Tammany had backed the gubernatorial bid of Grover Cleveland in 1882, only to have the governor quickly turn his broad back on Kelly and patronage for Tammany. Signing Roosevelt's bill in March 1884 certainly confirmed Cleveland's reformist tendencies, as cartoonists in Harper's Weekly and Puck depicted Roosevelt and Cleveland together taking on the Tammany tiger (Figure 1). ${ }^{53}$ In return, Kelly unsuccessfully opposed Cleveland's nomination for the presidency later that year, although after a secret meeting just weeks before the election Tammany grudgingly swung its support behind the Democratic nominee. Instead, Kelly focused Tammany's power on electing Hugh Grant for mayor. Election night found Kelly a sick and defeated man, as a hostile Cleveland won and the Tammany candidate Grant lost. Kelly left Tammany Hall that night never to return, handing the reins of power to his deputy Richard Croker. ${ }^{54}$

While it is hard to judge the lasting effect of Roosevelt's committee on the politics and governance of New York, it is easier to see the effect of the committee on Roosevelt and his career. For years to come Roosevelt would refer to his intimate knowledge of New York politics. In 1886 in an article in Century magazine, Roosevelt wrote an article on "Machine Politics in New York City," in which he recounted the committee hearings, including the large amounts of money that found its way through the city department heads to the political organizations. "The enormous emoluments of such officers are, of course, most effective in debauching politics. They bear no relation whatever to the trifling quantity of work done, and the chosen candidate readily recognizes what is the exact truth - namely, that the benefit of his service is expected to enure [hand over] to his party allies, and not to the citizens at large." ${ }^{55}$ In his 1891 history of New York, Roosevelt referred to the machine politicians as "a solid, welldisciplined army of evil." 56 Finally, the value of the committee hearings to Roosevelt's career cannot be underestimated. As Putnam says, in meeting the "constant opposition" and "exasperating difficulties" the committee faced, as its chairman Roosevelt

had not only given further proof of the toughness of his fiber, but had gained insights into a variety of details of municipal administration. The operation of machines in ward politics, the petty corruption at the district level, the power of bosses, their expedients and their channels of control, had been laid successively before him. He had had to handle everything from the evasions of a mayor to the defiance of an under-sheriff. If he had learned a great deal about the governing of a state at Albany, he had learned fully as much about the rule of a city in New York..$^{57}$

Roosevelt had not only proven himself a skilled and tough politician at age 25 , but he had shown what kind of politician he would become. Here was no Western cowboy or rural populist, but an urban reformer building his career in the city and state of New York. And despite his lifelong assertion of independence from strict party control, through the investigation of city corruption Roosevelt was clearly doing good work for 


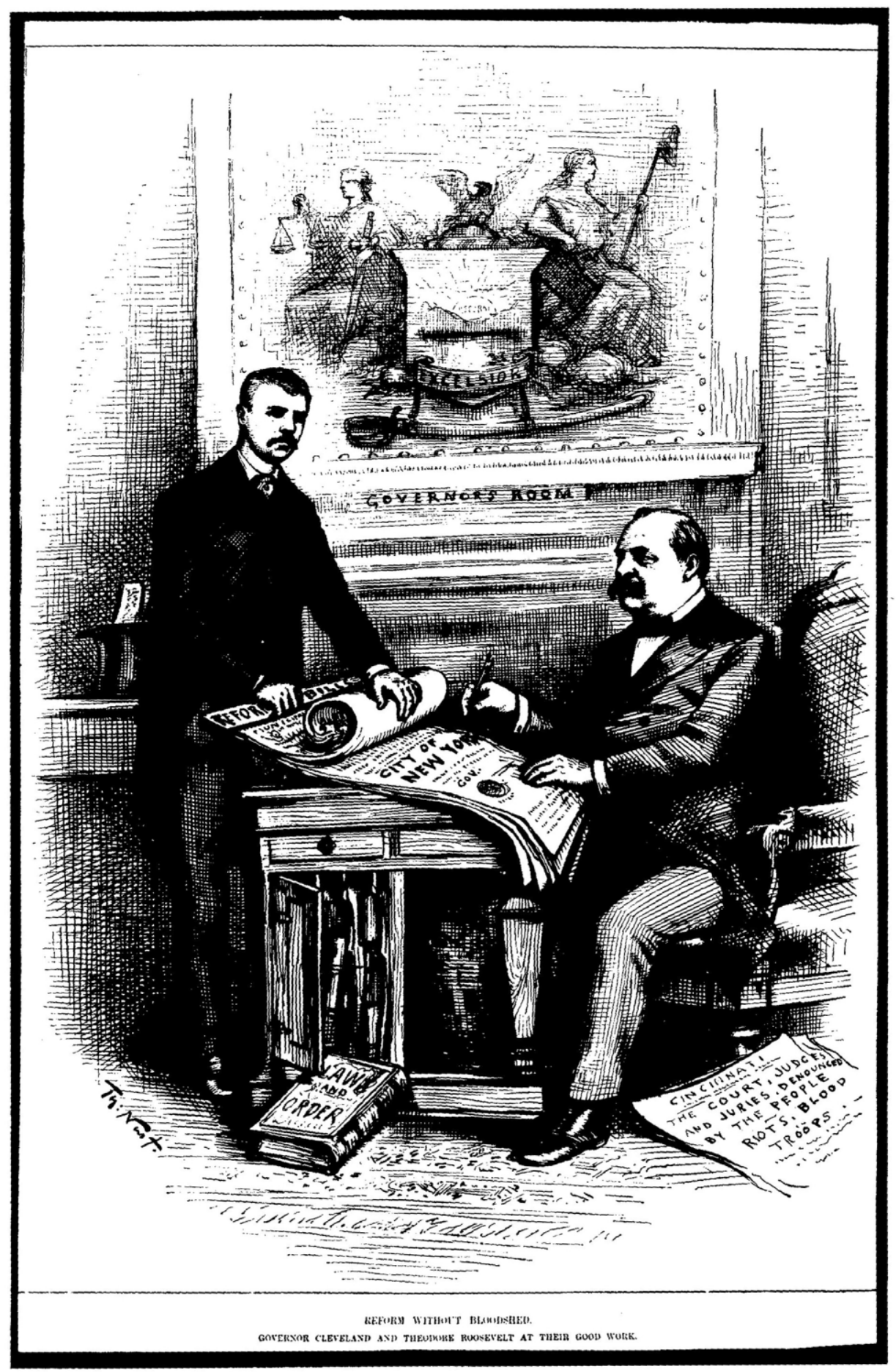

Figure 1. "Reform without bloodshed: Governor Cleveland and Theodore Roosevelt at their good work." Credit: Theodore Roosevelt Collection, Harvard College Library. 
the Republican party. Not only did the sensational revelations of Tammany shenanigans provide the sympathetic press with fodder for the front pages, but the resulting legislation, including the Aldermanic bill, directly attacked the power of city Democrats.

Roosevelt would of course go on to be a United States Civil Service Commissioner, as well as governor of New York. He also ran for mayor of New York in 1886, only to come in third in a three-way race. ${ }^{58}$ It was this brand of urban politics that would help put Roosevelt in the White House, not just his charge up Kettle Hill in Cuba. When Roosevelt's committee submitted their report in March 1884, they also asked for a continuation of the hearings in order to look into corruption in the New York police department. This extension of the committee's work has been seen as an important precursor to his work in New York City as president of the Board of Police Commissioners. Roosevelt's political path to the White House, then, must be traced through New York and Albany, rather than Cuba and the Bad Lands.

\section{Notes}

1. Harbaugh's Power and Responsibility: The Life and Times of Theodore Roosevelt contains a chapter titled "The Westerner: Rancher, Hunter, and Historian," in which Harbaugh says Roosevelt's time in the West was "one of the great formative experiences of his life" (48). Roosevelt's most recent biographer Aida Donald calls him "a divided man" (49).

2. Hunting Trips of a Ranchman, 1885; Ranch Life and the Hunting Trail, 1888; The Wilderness Hunter, 1893; The Winning of the West, 1889-1896. All can found in Roosevelt, The Works of Theodore Roosevelt.

3. Roosevelt, Theodore Roosevelt: An Autobiography, 96.

4. Pringle, Theodore Roosevelt: A Biography, chap. VIII.

5. Dalton, Theodore Roosevelt, 101; Brands, The Last Romantic, 185-6.

6. Morris, Rise of Theodore Roosevelt, chaps. 8, 11, 12, and 13, are dedicated to Roosevelt's Western experience, while an entire chapter, "The Long Arm of the Law," covers the two weeks that Roosevelt and others pursued boat thieves.

7. Interestingly, one of the most balanced assessments of the limited effect of the West on Roosevelt is G. Edward White's The Eastern Establishment and the Western Experience. White asserts that in the West Roosevelt "found health and confidence of a lasting nature." (93).

8. Cooper, The Warrior and the Priest, 30.

9. Roosevelt, Theodore Roosevelt: An Autobiography, 84.

10. Harbaugh, Power and Responsibility, 29. Yet even books on municipal reform of the period, while mentioning Roosevelt, do not bother to mention his committee. See Schiesl, Politics of Efficiency; Patton, Battle for Municipal Reform; Burrows and Wallace, Gotham; and Cerillo, "Reform of Municipal Government."

11. Brands, The Last Romantic, 166-7. Most Roosevelt biographers dedicate a page or two to the hearings, but few seem to have looked at the "Hearings" testimony itself. As Henry Pringle says, with Roosevelt's tragedy coming at the end of his Assembly career, his Albany accomplishments were "overshadowed by the death of his bride and his mother." Pringle barely mentions the committee and does not look at the Hearings. Pringle, Theodore Roosevelt: A Biography, 54-5. Kathleen Dalton and Nathan Miller barely mention the committee. Dalton, Theodore Roosevelt, 88, and Miller, Theodore Roosevelt, 153. Paul Grondhal echoes Harbaugh's assessment of the Hearings being therapy for Roosevelt, but has done little original research on the committee. Grondhal, I Rose Like a Rocket, 127-8, and 132-4. David McCullough provides a good explanation of the power of city aldermen and the big business of New York City government. McCullough, Mornings on Horseback, 
273-6, and 285-6. Even Roosevelt's own autobiography gives little information on the Hearings (Theodore Roosevelt: An Autobiography, 84-5). Edmund Morris uses the committee more as a framework within which to discuss Roosevelt's tragedy and Herculean work that followed. Morris, The Rise of Theodore Roosevelt, 235-7, and 248-51. Easily the best and most thorough account of Roosevelt's work chairing the committee is Putnam, Theodore Roosevelt, in particular pages 376-83, and 392-411.

12. Roosevelt was certainly one of the "dress suits" and "silk stockings" derided by Tammany politician George Washington Plunkitt. Riordon, Plunkitt of Tammany Hall, 50-53. Born in Gramercy Park and educated at Harvard, Roosevelt represented the "genteel" reformers interested in "citizenship, responsibility, efficiency, good government, economy, businesslike management" as Richard Hofstadter has described: "abstractions" that often isolated the reformer from the very people he claimed to be trying to help (The Age of Reform, 185). Indeed, John M. Allswang's 1977 Bosses, Machines, and Urban Voters: An American Symbiosis strongly asserts that the urban boss and his machine better served the needs of his constituents than reformers like Roosevelt. However, through studies of the New York machine and related topics such as police corruption, the "good-natured boss" thesis has been vigorously challenged over the past 30 years. See, among others, Daniel Czitrom's portrait of "Big Tim" Sullivan in "Underworlds and Underdogs," and Stephen Erie, Rainbow's End. Other historians have suggested alternatives to the boss-reformer duel. In his Unheralded Triumph, Jon C. Teaford suggests that the late nineteenth-century American city was not as bad as the reformers - or Lord Bryce - made them out to be, and focuses on city administration. More recently Teaford has suggested a series of topics just as important as bosses and reformers for evaluating city administration: mayors and other municipal officials; professional consultants; extralegal municipal actors, like real estate agents and fire insurance underwriters; police forces and fire brigades; and urban schooling. Teaford, "Finis for Tweed and Steffens." While a more balanced and nuanced view of the simplistic boss-reformer duel might be needed, this is not to say that the concerns of reformers like Roosevelt were without foundation. As David Thelen has pointedly asked, "Did the urban poor really prefer the boss's system of regulation whereby manufacturers and slumlords could provide unsafe and unhealthy living and working conditions in exchange for buying off the machine's inspectors?" He concludes: "Bosses may have helped some individual poor people when they needed jobs or when their kids got into trouble with the law, but they undoubtedly gave at least as much aid to saloonkeepers, manufacturers, and slumlords who got rich off the urban poor as they gave to the poor themselves." (“Urban Politics," 408.)

13. Roosevelt's interest in municipal reform arguably dated from his early adulthood. As Roosevelt began Harvard his father, Theodore Roosevelt, Sr., had become a pawn in a power struggle between President Rutherford Hayes and Roscoe Conkling's New York machine when Hayes named the elder Roosevelt to replace Chester A. Arthur as collector of the customs house for the Port of New York. Conkling attacked the nomination and the Senate rejected Roosevelt. At the time this was seen as a victory for Conkling's machine over the forces of reform, and Roosevelt's father died only two months later at age 46. (Reeves, Gentleman Boss, 125-31; Hoogenboom, Rutherford B. Hayes, 352-5.) At Harvard Roosevelt became lifelong friends with Richard Ward Greene Welling, who would become a prominent reformer, helping to organize the City Reform Club, the Good Government Clubs, and the National Municipal League. Morison, Letters of Theodore Roosevelt, footnote to 21. Roosevelt also helped start the Finance Club under the direction of his political economy professors, which heard presentations from William Graham Sumner, Francis A. Walker, Henry George, and Abram S. Hewitt. Morison, Letters of Theodore Roosevelt, footnote to 36. Roosevelt's early political career in the Assembly was sponsored by Joseph Choate, the prominent New York lawyer and old Roosevelt family friend who was an active anti-machine Republican "Swallowtail." Hammack, Power and Society, 140. And right from the beginning Roosevelt was active in reform-minded city organizations like the Union 
Club and the Municipal Reform League, and in 1882 had presided at the organization meeting of the City Reform Club. Morison, Letters of Theodore Roosevelt, footnote to 57. From an early age and at the very beginning of his political career, then, Roosevelt came into contact with the people and ideas shaping municipal reform in the United States. His Assembly career, including the Roosevelt bill and Roosevelt committee, were manifestations of this.

14. Burrows and Wallace, Gotham, 1009.

15. Quoted in Schiesl, The Politics of Efficiency, 7.

16. Ibid., 31-3. See also Teaford, The Unheralded Triumph; Griffith, History of American City Government; and Finegold, Experts and Politicians.

17. Bryce, The American Commonwealth, 637.

18. Patton, Battle for Municipal Reform, 18.

19. Ibid., 19.

20. New York State, Hearings, 1.

21. New York Times, January 20, 1884.

22. New York State, Hearings, 10.

23. New York Herald, January 20, 1884.

24. Putnam, Theodore Roosevelt, 378.

25. New York State, Hearings, 35-6.

26. Roosevelt, "Machine Politics," 85-6.

27. New York Herald, January 26, 1884.

28. Connable and Silberfarb, Tigers of Tammany Hall, 194.

29. New York State, Hearings, 57-8.

30. Ibid., 71.

31. The state senator was Thomas F. Grady. Putnam mistakenly asserts that it was under-sheriff Stevens who was arrested (Theodore Roosevelt, 380). New York Times, February 2 and 3, 1884.

32. New York Times, February 6, 1884. Even the Democratic New York Sun (February 6, 1884) credited Roosevelt with making "a lively onslaught on New York's aldermen," noting that he, "with Donnybrook impartiality, hit the heads of Republicans and Democrats alike in reference to city politicians."

33. Morison, Letters of Theodore Roosevelt, 65.

34. New York State, Hearings, 282-4. New York Times, February 10, 1884.

35. New York Sun, February 17, 1884.

36. New York Herald, February 10, 1884.

37. Harper's Weekly, February 16, 1884.

38. Morris, Rise of Theodore Roosevelt, 238.

39. New York Times, February 11, 1884. Echoing the Democratic opposition to the Aldermanic bill, the New York Sun (February 10, 1884) called for direct election of aldermen as preferable to "making the Mayor autocratic."

40. New York Times, February 14, 1884.

41. New York Times, February 15, 1884.

42. Morris, Rise of Theodore Roosevelt, 242.

43. Roosevelt, "The Mayor's Power of Removal," 34. Like other entries of the National Edition, this one is dated incorrectly, as the speech took place on 20 February.

44. New York Times, February 21, 1884.

45. New York State, Hearings, 378-9.

46. Ibid., 429-39.

47. Ibid., 818 .

48. New York Times, March 2, 1884.

49. New York Times, March 6, 1884.

50. Hagedorn, Harvard Club Interview.

51. New York State, Report, 1.

52. Ibid., 1-13. 
53. Cartoon "Reform Without Bloodshed: Governor Cleveland and Theodore Roosevelt at Their Good Work," Harper's Weekly, April 19, 1884; and cartoon “Made Harmless at Last!” Puck, March 25, 1884. The Puck cartoon shows Roosevelt and Cleveland walking arm-in-arm, with Roosevelt carrying a large pair of scissors labeled "Roosevelt Bill.” He gestures toward a weeping Tammany Tiger who has been shorn of his claws marked "Confirming Power," while sitting on a chair labeled "Board of Aldermen."

54. See Myers, History of Tammany Hall, 262; Connable and Silberfarb, Tigers of Tammany Hall, 195-6; Werner, Tammany Hall, 300-3; and Allen, The Tiger, 168-9. None of the authors mentions Kelly testifying before the committee, the pre-election meeting with Edson, or the Aldermanic bill as a threat to Tammany patronage. In fact, the authors all agree that Kelly left Tammany stronger and scandal-free.

55. Roosevelt, "Machine Politics," 85-6.

56. Roosevelt, "New York," 533.

57. Putnam, Theodore Roosevelt, 405.

58. Roosevelt ran against United Labor Party candidate Henry George and reform Democrat Abram Hewitt. From the beginning Roosevelt and other Republicans knew it was a "perfectly hopeless contest," as Roosevelt himself wrote to Henry Cabot Lodge before the election. It was widely expected that George's "radical" advocacy of a land tax and sympathy for the working poor would drive many Republicans to vote for Hewitt. Roosevelt agreed to run anyway as a "sacrifice candidate" for the good of the party: uniting New York Republicans who in 1884 had divided over the party's presidential nomination. Despite Roosevelt's 1886 loss, in 1888 a united Republican party delivered its 32 electoral votes to Republican Benjamin Harrison by a margin of 13,000 votes, defeating former New York governor Grover Cleveland. See Kohn, "A Necessary Defeat.”

\section{References}

Allen, Oliver E. The Tiger: The Rise and Fall of Tammany Hall. Reading, MA: Addison-Wesley Publishing Company, 1993.

Allswang, John M. Bosses, Machines, and Urban Voters: An American Symbiosis. Port Washington, NY: Kennikat Press, 1997.

Brands, H.W. TR: The Last Romantic. New York: Basic Books, 1997.

Bryce, James. The American Commonwealth. 1905 ed, vol. I. New York: Macmillan and Company, 1893.

Burrows, Edwin G., and Mike Wallace. Gotham: A History of New York to 1898. New York: Oxford University Press, 1999.

Cerillo, Augustus Jr. “The Reform of Municipal Government in New York City.” New-York Historical Society Quarterly 57, no. 1 (1973): 51-71.

Connable, Alfred, and Edward Silberfarb. Tigers of Tammany Hall: Nine Men Who Ran New York. New York: Holt, Rinehart and Winston, 1967.

Cooper, John Milton Jr. The Warrior and the Priest: Woodrow Wilson and Theodore Roosevelt. Cambridge, MA: Harvard University Press, 1983.

Czitrom, Daniel, "Underworlds and Underdogs: Big Tim Sullivan and Metropolitan Politics in New York, 1889-1913.” Journal of American History 78, no. 2 (September 1991): 536-58.

Dalton, Kathleen. Theodore Roosevelt: A Strenuous Life. New York: Vintage Books, 2002.

Erie, Stephen. Rainbow's End: Irish-Americans and the Dilemmas of Urban Machine Politics, 1840-1985. Berkeley and Los Angeles: University of California Press, 1988.

Finegold, Kenneth. Experts and Politicians: Reform Challenges to Machine Politics in New York, Cleveland, and Chicago. Princeton, NJ: Princeton University Press, 1995.

Griffith, Ernest. A History of American City Government: The Conspicuous Failure, 1870-1900. New York: Praeger, 1974.

Grondhal, Paul. I Rose Like a Rocket: The Political Education of Theodore Roosevelt. New York: Free Press, 2004. 
Hagedorn, Herman. Harvard Club Interview with Isaac Hunt, September 20, 1923, Theodore Roosevelt Collection, Houghton Library, Harvard University.

Hammack, David C. Power and Society: Greater New York at the Turn of the Century. New York: Russell Sage Foundation, 1982.

Harbaugh, William Henry. Power and Responsibility: The Life and Times of Theodore Roosevelt. New York: Farrar, Straus and Cudahy, 1961.

Hofstadter, Richard. The Age of Reform: From Bryan to F.D.R. New York: Vintage Books, 1955.

Hoogenboom, Ari. Rutherford B. Hayes: Warrior and President. Lawrence, KA: University Press of Kansas, 1995.

Kohn, Edward P. "A Necessary Defeat: Theodore Roosevelt and the New York Mayoral Election of 1886." New York History 87, no. 2 (Spring 2006): 205-27.

McCullough, David. Mornings on Horseback. New York: Simon and Schuster, 1981.

Miller, Nathan. Theodore Roosevelt: A Life. New York: Morrow and Company, 1992.

Morison, Elting E., ed. The Letters of Theodore Roosevelt. Cambridge, MA: Harvard University Press, 1951.

Morris, Edmund. The Rise of Theodore Roosevelt. New York: Coward, McCann and Geoghegan, Inc., 1979.

Myers, Gustavus. The History of Tammany Hall. New York: Dover Publications, Inc., 1971.

New York State. Report of the City Investigating Committee, 14 March 1884.

New York State, Special Committee Appointed to Investigate the Local Government of the City and County of New York. Hearings, vol. I, 1884.

Patton, Clifford W. The Battle for Municipal Reform: Mobilization and Attack, 1875-1900. College Park, Maryland: McGrath Publishing Company, 1969.

Pringle, Henry. Theodore Roosevelt: A Biography. 1984 ed. New York: Harcourt Brace and Company 1931.

Putnam, Carleton. Theodore Roosevelt: The Formative Years, 1858-1886. New York: Charles Scribner's Sons, 1958.

Reeves, Thomas C. Gentleman Boss: The Life of Chester Alan Arthur. New York: Alfred A. Knopf, 1975.

Riordon, William R. Plunkitt of Tammany Hall: A Series of Very Plain Talks on Very Practical Politics. New York: Signet Classic, 1995.

Roosevelt, Theodore. "Machine Politics in New York City." In The Works of Theodore Roosevelt, national ed, vol. XII, 76-98. New York: Charles Scribner's Sons, 1926.

_. "The Mayor's Power of Removal." Speech in Assembly, 12 March 1884. In The Works of Theodore Roosevelt, national ed, vol. XIV, 33-6. New York: Charles Scribner's Sons, 1926.

- "New York." In The Works of Theodore Roosevelt, national ed., vol. X, 365-47. New York: Charles Scribner's Sons, 1926.

- Theodore Roosevelt: An Autobiography. Reprint. New York: Da Capo Press, 1984.

Schiesl, Martin J. The Politics of Efficiency: Municipal Administration and Reform in America: 1880-1920. Berkeley: University of California Press, 1977.

Teaford, Jon C. "Finis for Tweed and Steffens: Rewriting the History of Urban Rule." Reviews in American History 10, no. 4 (December 1982): 133-49.

. The Unheralded Triumph: City Government in America, 1870-1900. Baltimore, Maryland: The Johns Hopkins University Press, 1984.

Thelen, David. "Urban Politics: Beyond Bosses and Reformers." Reviews in American History 7, no. 3 (September 1979): 406-12.

Werner, M.R. Tammany Hall. New York: Doubleday, Doran and Company, Inc., 1928.

White, G. Edward. The Eastern Establishment and the Western Experience: The West of Frederic Remington, Theodore Roosevelt, and Owen Wister. University of Texas Press edition. Austin, Texas: University of Texas Press, 1989. 